Supporting information for World Wide Web edition

\title{
STRUCTURAL BASIS FOR CATALYTIC ACTIVITY AND ENZYME POLYMERIZATION \\ OF PHOSPHOLIPID HYDROPEROXIDE GLUTATHIONE PEROXIDASE-4 (GPX4)
}

\author{
Patrick Scheerer, Astrid Borchert, Norbert Krauß, Helga Wessner, Christa Gerth, Wolfgang \\ Höhne and Hartmut Kuhn
}

\section{Institute of Biochemistry, University Medicine Berlin - Charite, Monbijoustr. 2, D-10117 Berlin, Germany}

Running title: GPx4 structure and function

*Correspondence should be addressed to: Dr. Hartmut Kuhn, Institute for Biochemistry, University Medicine Berlin - Charité, Monbijoustr. 2, D-10117 Berlin, Germany, Tel. +49-30-450 528040, Fax +49-30-450 528905, e-mail: hartmut.kuehn@charite.de

\section{Supplementary methodological information}

\subsection{Enzyme expression and purification}

For expression bacteria were transformed with the recombinant plasmid and grown overnight at $37^{\circ} \mathrm{C}$ in $25 \mathrm{ml} \mathrm{LB}$ medium containing $100 \mu \mathrm{g} / \mathrm{ml}$ ampicillin and $25 \mu \mathrm{g} / \mathrm{ml}$ kanamycin. $10 \mathrm{ml}$ of the overnight culture were added to $11 \mathrm{LB}$ medium containing antibiotics and the bacteria were cultured at $37^{\circ} \mathrm{C}$ to an $\mathrm{OD}_{600}$ of 0.6. Expression of the recombinant enzyme was then induced by addition of isopropyl-D-thiogalactopyranoside $(1 \mathrm{mM})$ and bacteria were further cultured at $30^{\circ} \mathrm{C}$ for 2 hours. The cells were harvested by centrifugation, the pellet was resuspended in $40 \mathrm{ml}$ lysis buffer $(0.1 \mathrm{M}$ Tris/Cl, pH 8 containing $300 \mathrm{mM}$ sodium chloride and $20 \mathrm{mM}$ imidazole) and incubated on ice with 1 $\mathrm{mg} / \mathrm{ml}$ lysozyme for $30 \mathrm{~min}$. After sonication (30 times for $0.5 \mathrm{~s}$ at $40 \mathrm{~W}$ with tip sonifier; Braun, Melsungen, Germany) the lysate was centrifuged at $10,000 \mathrm{x}$ g for $20 \mathrm{~min}$ at $4^{\circ} \mathrm{C}$ and the supernatant was applied onto $5 \mathrm{ml}$ of Ni-NTA-matrix column (QIAGEN, Hilden, Germany), which was previously equilibrated with lysis buffer. Unbound protein was washed away twice with $5 \mathrm{ml}$ washing buffer $(0.1$ $\mathrm{M}$ Tris/Cl, pH 8 containing $300 \mathrm{mM}$ sodium chloride and $50 \mathrm{mM}$ imidazole), the his-tagged GPx4 was eluted with an increasing imidazole step-gradient (100-250 $\mathrm{mM}$ in steps of $50 \mathrm{mM})$ and the recombinant enzyme was identified in the different fractions by immunoblotting using a home made monoclonal anti human GPx4 antibody (data not shown). In typical experiments the majority of GPx4 was eluted in fractions 1-4 as indicated in the upper inset of Fig. S1. These fractions were pooled and subjected to dialysis to remove the bulk of imidazole. After dialysis for $12 \mathrm{~h}(0.1 \mathrm{M}$ Tris/Cl buffer, $\mathrm{pH}$ 7.4 containing $1 \mathrm{mM}$ DTT) the preparation was re-purified by FPLC on a Mono-Q anion exchange 
column. An example chromatogram of the final preparation step is given in (Fig. S1). The recombinant enzyme was eluted from the column at a $\mathrm{NaCl}$ concentration of about $0.05 \mathrm{mM}$. The final enzyme preparation was more than $95 \%$ pure as indicated by SDS-PAGE (lower inset)

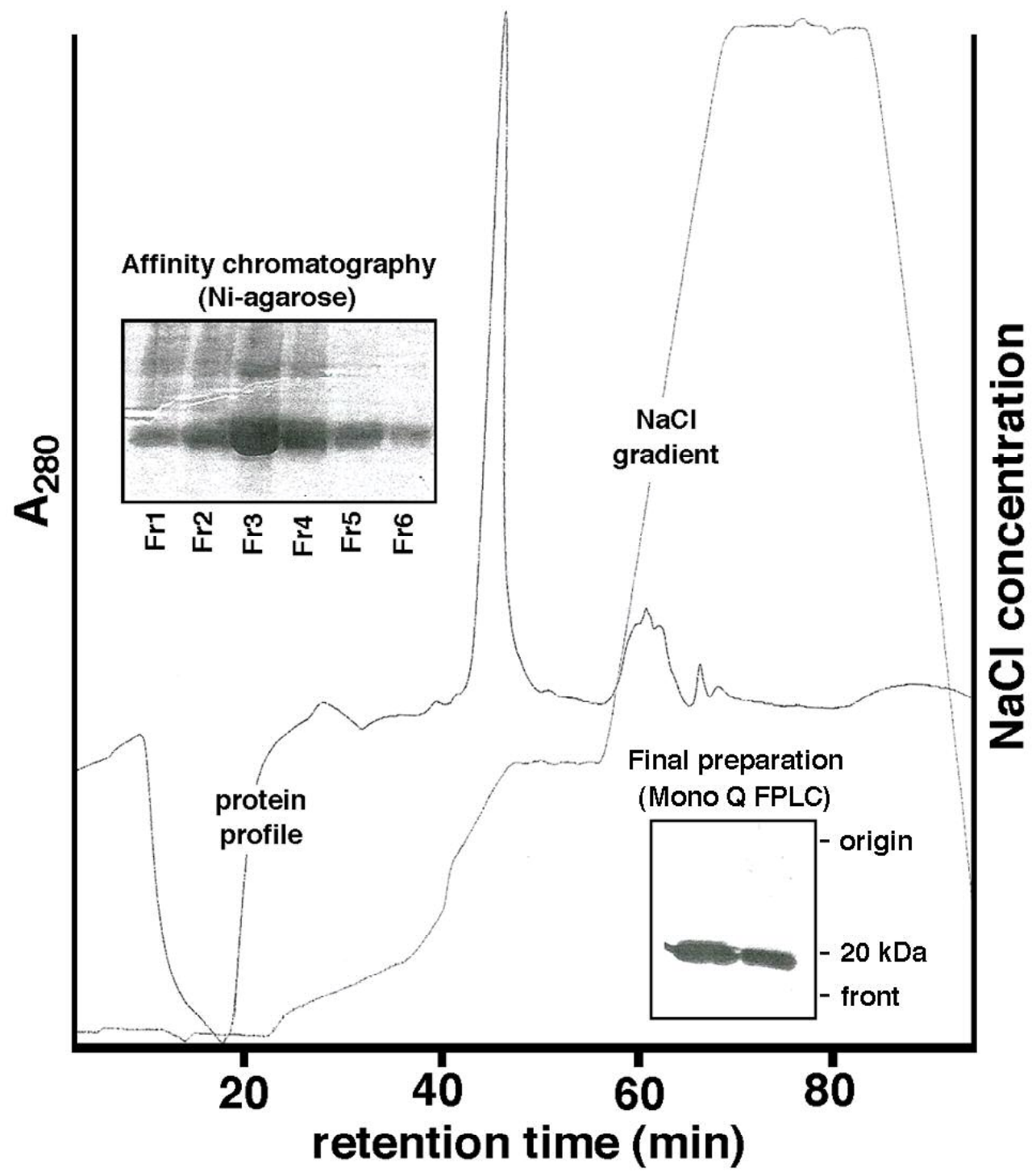

Fig. S1 Purification of the U46C mutant of recombinant human cytosolic GPx4. The elution profile of proteins from the Mono-Q FPLC column using an increasing $\mathrm{NaCl}$ gradient is shown. Degree of purity of the final enzyme preparation (lower right inset) was $>95 \%$ as indicated by Coomassie-staining of the electropherogram. GPx4 content of different fractions of Ni-agarose column (upper left inset) was analyzed by electrophoresis (Coomassie-staining).

\section{Supplementary experimental information}

\subsection{Crystal trials}

The experimental conditions for protein crystallization are described in the main part of the ms.

Fig. S2 shows a representative image of the GPx4 crystals as they were used for X-ray diffraction experiments. 


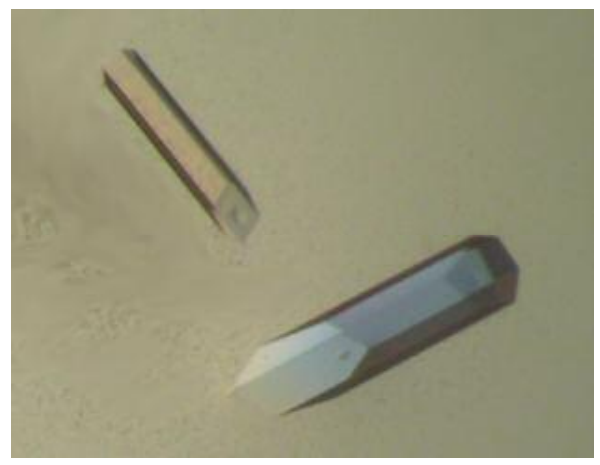

Fig. S2. GPx4 crystals used for X-ray diffraction experiments.

\subsection{Data collection and refinement statistics}

Table S1 Parameters of data collection and structure refinement

\begin{tabular}{|c|c|}
\hline Beamline & BL14.1 (BESSY, Berlin, Germany) \\
\hline Wavelength $[\AA]$ & 0.9537 \\
\hline Temperature $[\mathrm{K}]$ & 100 \\
\hline No. crystals & 1 \\
\hline Space group & $\mathrm{P} 3{ }_{1} 21$ \\
\hline Unit cell dimensions & $\mathrm{a}=\mathrm{b}=61.36 \AA, \mathrm{c}=113.89 \AA, \alpha=\beta=90^{\circ}, \gamma=120^{\circ}$ \\
\hline Resolution range / (outer shell) $[\AA]$ & $50.00-1.55 /(1.61-1.55)$ \\
\hline $\begin{array}{l}\text { No. of observations } \\
\text { No. of unique reflections } \\
\text { Redundancy }\end{array}$ & $\begin{array}{l}331435 \\
35135 \\
9.4\end{array}$ \\
\hline Completeness overall / (outer shell) [\%] & $95.6 /(66.6)$ \\
\hline$<I / \sigma(I)>$ overall / (outer shell) & $19.15 /(2.56)$ \\
\hline Wilson B-factor $\left[\AA^{2}\right]$ & 18.68 \\
\hline$R_{\text {merge }}{ }^{1}(\%)$ overall / (outer shell) & $6.8 /(36.4)$ \\
\hline Solvent content $[\%] / V_{m}\left(\AA^{3} / \mathrm{Da}\right)^{4}$ & $58.37 / 2.95$ \\
\hline Resolution Range used during refinement $[\AA]$ & $30.69-1.55$ \\
\hline No. of reflections & 33339 \\
\hline $\begin{array}{l}R_{\text {cryst }}{ }^{2}[\%] / \text { / (Number of reflections) } \\
R_{\text {free }}[\%] / \text { (Number of reflections) }\end{array}$ & $\begin{array}{l}16.4 /(31578) \\
18.6 /(1761) \\
\end{array}$ \\
\hline $\begin{array}{l}\text { No. of amino acid residues / (No. of atoms) } \\
\text { No. of water molecules }\end{array}$ & $\begin{array}{l}165 /(1347) \\
151\end{array}$ \\
\hline $\begin{array}{l}\text { Average B factors }\left[\AA^{2}\right] \\
\text { All atoms } \\
\text { Min } \\
\text { Max }\end{array}$ & $\begin{array}{l}8.5 \\
2.1 \\
45.5\end{array}$ \\
\hline $\begin{array}{l}\text { rmsd from ideal geometry } \\
\text { bond lengths }[\AA] \\
\text { bond angles }\left[{ }^{\circ}\right]\end{array}$ & $\begin{array}{l}0.015 \\
1.276\end{array}$ \\
\hline
\end{tabular}

${ }^{1} R_{\text {merge }}=\sum_{h k l} \sum_{j}\left|I_{h k l}(j)-\left\langle I_{h k l}\right\rangle\right| / \sum_{h k l} \sum_{j} I_{h k l}(j)$, where $\left\langle I_{h k l}\right\rangle$ is the mean intensity and

$I_{h k l}(j)$ are individual intensity measurements of the reflection $(h k l)$.

${ }^{2} R_{\text {cryst }}=\sum_{h k l}\left|F_{h k l}(o b s)-F_{h k l}(c a l c)\right| / \sum_{h k l} F_{h k l}(o b s)$

${ }^{3} R_{\text {free }}$ is the same as R-factor $R_{\text {cryst }}$ but calculated with $5 \%$ of the reflections that were excluded from refinement.

${ }^{4}$ Mathews, B. W. (1968) Solvent content of protein crystals. J. Mol. Biol. 33, 491-497

${ }^{5}$ Engh, R. A., and Huber, R. (1991) Accurate bond and angle parameters for X-ray protein structure refinement. Acta

Crystallogr. A 47, 392-400 
In Table S1 important parameters of data collection and the refinement statistics are summarized. The final structural model of human GPx4 is shown in Fig. 1 of the main paper. The enzyme consists of four $\alpha$-helices that are localized at the protein surface and seven $\beta$-strands, five of which are clustered to form a central ß-sheet. The catalytic triad consisting of C46, Q81 and W136 is localized at a flat impression of the protein surface. The elements of the secondary structure and their localization in the amino acid sequence of the human cytosolic GPx4 are summarized in Table S2.

Table S2. Secondary structural elements of human cytosolic GPx4 and assignment in the primary structure

\begin{tabular}{|l|l|}
\hline \hline Element & Residues \\
\hline \hline $3_{10}^{\prime}$ & $8-10$ \\
\hline $3_{10}$ & $14-16$ \\
\hline$\beta 1$ & $18-21$ \\
\hline$\beta 2$ & $24-28$ \\
\hline $3^{\prime \prime} 10$ & $30-32$ \\
\hline$\beta 3$ & $36-42$ \\
\hline$\alpha 1$ & $48-66$ \\
\hline$\beta 4$ & $68-75$ \\
\hline$\alpha 2$ & $86-96$ \\
\hline$\beta 5$ & $101-103$ \\
\hline$\alpha 3$ & $115-122$ \\
\hline$\beta 6$ & $138-143$ \\
\hline$\beta 7$ & $150-153$ \\
\hline$\alpha 4$ & $159-170$ \\
\hline \hline
\end{tabular}

\subsection{Assay of GPx4 activity using $t$-butyl-hydroperoxide as substrate}

Composition of the reaction mixture is described in the Material and Methods section. For activity assays the enzyme preparation was pre-incubated in the assay mix in the absence of substrate and the absorbance at $340 \mathrm{~nm}$ was monitored.

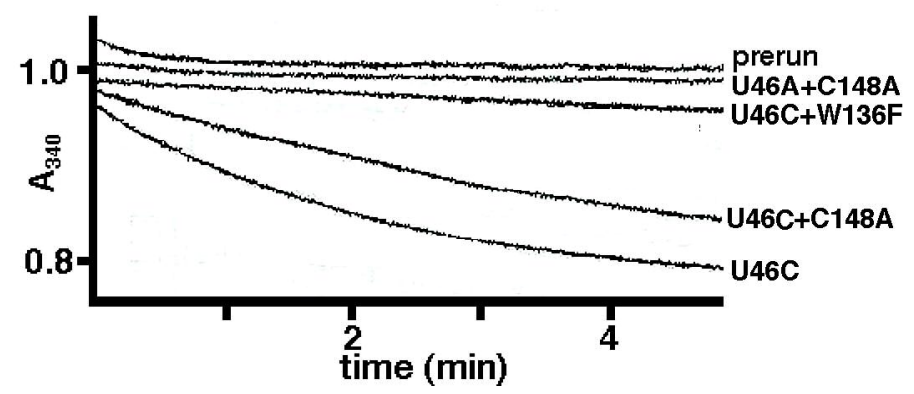

Fig. S3. Activity assays of GPx4 mutants. Equal amounts of pure GPx4 mutant proteins were added for spectrophotometric activity assays as described in Material and Methods.

When the baseline was stable (no further decrease in $\mathrm{A}_{340}$ ) the GPx4 reaction was initiated by addition t-butyl hydroperoxide as substrate at a final concentration of $25 \mu \mathrm{M}$. The duration of the preincubation period varied between 3-5 min. After substrate addition the decrease in absorbance at 340 was assayed over a time period of $5 \mathrm{~min}$. In Fig. $\mathbf{S 3}$ representative kinetic progress curves are shown. 